SANJA MAJER-BOBETKO

HRVATSKA AKADEMIJA ZNANOSTI I UMJETNOSTI

\title{
BETWEEN MUSIC AND IDEOLOGIES: CROATIAN MUSIC CRITICISM FROM THE BEGINNING TO WORLD WAR II*
}

C roatian music criticism has not yet been completely researched, and all the research carried out to date has been sporadic and unsystematic. As the Croatian lands were exposed to often aggressive Austrian, Hungarian and Italian politics until World War I and in some regions even later, ${ }^{\mathrm{I}}$ Croatian music criticism was written in Croatian, German and Italian. At the beginning of the nineteenth century, Croatian was mainly the language of the lower classes. In I843 the nobleman Ivan Kukuljević-Sakcinski was the first to speak Croatian instead of Latin in the Croatian Parliament. Yet Croatian only became the official language in 1847 .

To the best of our knowledge, the first ever piece of Croatian music criticism was written in I826, in the literary and entertainment journal Luna, by an anonymous author writing in German. ${ }^{2}$ The musicologist Lovro Županović attributes that review to Franjo Ksaver (Serafin) Stauduar (b. I825 or I826; d. I864), who was the newspaper's publisher and editor. Stauduar wrote a report in the Wiener allgemeine Theaterzeitung on a performance of the first Croatian national opera, Ljubav i zloba [Love and Malice], by Vatroslav Lisinski (I8I9-54), from I846, 'which may also mean that he was personally in charge of the theatre section in Luna'. ${ }^{3}$ The first music review concerned the five-act melodrama Viola by the German dramatist Joseph Auffenberg (I798-I857), with music by Georg (Juraj) Karl Wisner von Mor-

* Part of this text results from research conducted within the project 'Networking through music: Changes of paradigms in the "Long I9th Century" - from Luka Sorkočević to Franjo Ks. Kuhač" (NETMUSig; IP-06-20I6-4476), financed by the Croatian Science Foundation (20I7-2I).

I The city of Zadar belonged to the Habsburg Monarchy until the collapse of the Austro-Hungarian Empire and then to Italy until 1944, like Rijeka (until 1947).

2 The author's name was signed '- au -'.

3 Lovro Županović, Centuries of Croatian music, vol. 2, Zagreb i989, p. II7. 
genstern (1783-I855). In the second half of the century, the most prominent critic writing in German was Heinrich Hirschl, about whom no biographic information has yet come to light. His music critiques, published in the I87os and I880s in the German-language newspapers of Zagreb, were analysed by Snježana Miklaušić-Ćeran, who concluded that he was mainly an opera critic, also well acquainted with the concert literature. The points he made were always well argued. ${ }^{5}$ While it is true that music criticism published in nineteenth-century German-language newspapers is generally more sophisticated than that published in Croatian, ${ }^{6}$ the situation started to change towards the end of the century. From the beginning of the twentieth century, and especially during the period from World War I until 1945 (when German-language newspapers stopped being published), that was no longer the case. Moreover, it was not uncommon for the same critics to write in both languages, and sometimes the same criticism.

Among those who wrote in Italian, the most prominent was Giovanni Salghetti Drioli (I8I7-68), a popular composer, organiser of musical life in Zadar and discerning music critic for the Osservatore dalmato. ${ }^{7}$ According to Ennio Stipčević, Drioli excelled in music criticism characterised by lucid observations and a vivid writing style. His criticism had a great impact on musicians, because his judgements were based on merit. $^{8}$

A forum for Croatian-language music criticism was opened in 1835 by Novine Horvatzke in its literary supplement Danica horvatska, slavonska $i$ dalmatinska, ${ }^{9}$ which officially started to promote the Croatian National Revival. However, those articles cannot be considered music criticism, at least not in the modern sense of the

4 Born in Arad (now in Romania), Wisner von Morgenstern arrived in Zagreb in I8I8 and for decades was a leading figure in the city's musical life. For more information, see Nada Bezić, 'Prilozi za biografiju Georga (Jurja) Karla Wisnera von Morgensterna uoči I50. obljetnice smrti’ [Supplements to the biography of Georg (Juraj) Karl Wisner von Morgenstern, on the forthcoming I5oth anniversary of his death], Arti musices 35 (2004) no. I, pp. 47-6I.

5 Cf. Snježana Miklaušić-Ćeran, 'Glazbeni kritičar Heinrich Hirschl. Prilog proučavanju glazbene kritike u Hrvatskoj u drugoj polovini 19. stoljeća' [The music critic Heinrich Hirschl. A contribution to the study of music criticism in Croatia in the second half of the nineteenth century], Arti musices 27 (I996) no. 2, pp. $135-160$.

6 See e.g. Snježana Miklaušić-Ćeran, 'Odrazi koncertnoga života Zagreba između I826. i I858. u zagrebačkim novinama i časopisima' [Reflections of Zagreb concert life between 1826 and I858 in Zagreb newspapers and journals], Academy of Music, University of Zagreb 2012 (unpublished PhD dissertation).

7 An extensive biography of Giovanni Salghetti Drioli was written by Lorenzo Benevenia, Giovanni Salghetti-Drioli, Zadar 1904, ${ }^{2}$ I936.

8 Cf. Ennio Stipčević, 'Glazbeni život u Zadru I860-I9I8' [Musical life in Zadar I860-I9I8], Zadarska revija 34 (1985) no. I, p. 87.

9 From I836 to I843 the title was Danica ilirska [Illyrian morning star]. After Vienna banned the Illyrian name, in 1843 , the title was changed to Danica horvatska, slavonska $i$ dalmatinska [Croatian, Slavonic and Dalmatian morning star] (I843-48), but the original title was restored in 1849 and under that title Danica was published until 1867 . 
term, as they never went beyond the level of mere journalistic reports. Ambitious overviews began to appear in Danica after 1839, mainly in the contributions of Dimitrija Demeter (I8II-72), ${ }^{\mathrm{IO}}$ a poet and playwright of Greek origin, but the first real music criticism in Croatian is generally considered to be a comprehensive text by another poet, the Slovenian-born Stanko Vraz (I8IO-5I). He wrote in Danica about a performance of Lisinski's Love and Malice. ${ }^{\text {II }}$ In terms of its judgement criteria, that critique became a model for the majority of nineteenth-century Croatian music criticism, at least for that written in Croatian. Two criteria are clearly expressed within it: the national and the artistic. For example, writing about choral numbers, he pointed out: 'We must thank them [the singers; Vraz himself was a member of the chorus] sincerely, on behalf of all patriots, for their kindness and for the trouble they took to present our first musical work as it deserved. This is the best proof of their love for the motherland!' ${ }^{12}$ On the other hand, this criticism displayed an ambition to educate readers about the meaning of a musical work or how to listen to it. Thus Vraz wrote the following about Lisinski's overture: 'Already the overture, with its delightful national tunes and truly masterful harmony, aroused the attention of the large audience. ${ }^{\text {I3 }}$

The era of Bach's Absolutism (1850-59, named after the Viennese Minister of the Interior) or neo-Absolutism, as it is now known, suppressed the ideas of the Revivalists, and so the emphasis on patriotism was stifled, albeit not entirely. The nationalist criterion in music criticism was strongly revived after 1860, being particularly promoted by the founder of Croatian ethnomusicology and music historiography Franjo Ksaver Kuhač (I834-I9II). ${ }^{\text {I4 }}$ On the other hand, together with the professional music teacher and organist Vjenceslav Novak (I859-1905), a prominent representative of Croatian literary realism and author of the first general

IO Dimitrija Demeter was a distinguished playwright and impresario. He also revised Janko Car's (I822-76) libretto for Lisinski's opera Love and Malice and wrote the libretto for Lisinski's opera Porin (I85I, premiered in 1897).

II Stanko Vraz, 'Pàrva izvorna ilirska opera "Ljubav i zloba" od Vatroslava Lisinskoga' [The first genuine Illyrian opera, Love and Malice by Vatroslav Lisinski], Danica horvatska, slavonska i dalmatinska I2 (4 April I846) no. I4, pp. 53-56; I2 (II April I846), pp. 57-60.

I2 Quoted after Lovro Županović, Centuries of Croatian music, op. cit., vol. 2, p. II6.

I3 Ibid.

I4 His lifework consists of four volumes of South Slavic folk songs (I878-8I) containing I60o songs. The fifth volume (400 songs), prepared by Božidar Širola and Vladoje Dukat, was published in 194I. The material for the sixth and seventh volumes is still in manuscript. Besides numerous articles, essays and comprehensive studies in the fields of ethnomusicology and music historiography, he wrote the first monograph on the most prominent composer of Croatian romanticism, Vatroslav Lisinski (I887), and a series of portraits of other representatives of the period (Ilirski glazbenici [Illyrian musicians], I893). He was also the first to introduce the term musicology into the Croatian culturological space. He did so before Adler, in his unpublished study 'Die Eigenthümlichkeiten der magyarischen Volksmusik', from I884, and then a year after Adler (in 1886) in the journal Vienac. 
history of music in Croatia, ${ }^{15}$ Kuhač started the process of professionalisation in the field of musicology and music criticism written in Croatian. While Kuhač based his criticism on his strong conviction that criticism and even historiography, not just music itself, must support and promote the national identity, Novak focussed on genuine questions of aesthetics, promoting first and foremost Hanslick's idea of music as an autonomous art form. ${ }^{16}$ It is important to mention here that Kuhač initiated professional writing and speaking about music in Croatian. He also translated Lobe's Katechismus der Musik. Published in I875 and again in I889, that translation, although quite clumsy in many places, represented the first attempt at creating a standard Croatian musical terminology. A considerable number of Kuhač's terms have become part of that terminology, which in some respects is still a work in progress.

The turn of the century saw the emergence of the Croatian poet and writer Antun Gustav Matoš (I873-I9I4), who became a central figure in the Croatian moderna. Insisting that critical ability, like artistic talent, was innate, Matoš founded impressionist Croatian music criticism, based on a subjective approach to the musical work. Impressionist criticism often devotes more attention to stylistic perfection than to the complexity of critical analysis, and the emphasis is not on what has been said, but on how it was expressed, that is, on the literary value of a critical piece. That was the case with Matoš himself, who, in his search for artistic values and his judgement of them, relied exclusively on his own taste, all the more so because of his impulsive and oversensitive nature. That, of course, provided a basis for criticism on the grounds of subjectivity. Relying on his fascinating artistic intuition, which was the main - and too often the only - basis for his understanding and experiencing of a musical work, he passionately pleaded for European aesthetic criteria and against anything that could jeopardise art. ${ }^{17}$ We may conclude that Matoš was the only Croatian critic of the time whose criticism corresponded to Oscar Wilde's I89o definition of the critic as an artist. However, he also believed that true art and music had to be national. At the same time as Matoš, and following the same ideas, the prominent writer Milutin Cihlar Nehajev (I880-I93I), ${ }^{18}$ who was among those who wrote in both Croatian

I5 It remained at that time in manuscript only. A critical edition with a list of musical terminology and an introductory study was prepared by Sanja Majer-Bobetko and published in: Croatica 25 (I994) no. 4O-4I, pp. I-200.

I6 Cf. Sanja Majer-Bobetko, Estetika glazbe u Hrvatskoj u I9. stoljeću [Music aesthetics in Croatia in the nineteenth century], Zagreb I979, pp. I7-40; Zdravko Blažeković, 'Franjo Ksaver Kuhač: utemeljitelj hrvatske glazbene historiografije’ [Franjo Ksaver Kuhač: The founder of Croatian music historiography], in: Sanja Majer-Bobetko, Zdravko Blažeković and Gorana Doliner, Hrvatska glazbena historiografija u I9. stoljeću [Croatian music historiography in the nineteenth century], Zagreb 2009, pp. 34-IOo.

I7 Cf. S. Majer-Bobetko, Estetika glazbe, op. cit., pp. 6o-72; eadem, 'Matošev život s glazbom' [Matošs life with music], Hrvatska revija I4 (20I4) no. I, pp. 2I-24.

I8 On Milutin Cihlar Nehajev's criticism see Nedjeljko Fabrio, 'Milutin Cihlar Nehajev i ars musicae' [Milutin Cihlar Nehajev and ars musicae], Forum 25 (1986) no. I-2, pp. I76-209. 
and German, started his career as a music critic, and in the twentieth century he was immediately followed by the poet Nikola Polić (I890-1960). ${ }^{19}$

Alongside the tradition of impressionistic criticism, the tradition of ideological-utilitarian criticism, conceived during the Croatian National Revival and later advocated by Franjo Kuhač, which was aimed at promoting the national ideology, was continued and came to dominate the thinking of numerous critics during the period after World War I. The most prominent ideologist at that time was the composer, music writer and critic Antun Dobronić (1878-1955), influenced by Kuhačs views and by his own studies at the Prague conservatory (I9IO-I2) with Vítězslav Novák. However, Dobronić was not satisfied by simply promoting nationalism in music criticism, which tended to 'define the proper role of Croatian music' in general music history, as historian Josip Andreis (1909-82) wrote in $1942,{ }^{20}$ and to show the importance of national style in music as 'an excellent instrument in the struggle for political independence'. ${ }^{2 I}$ Unfortunately, from time to time his criticism bore the stamp of chauvinistic nationalism, as he predicted that Slavic music would soon enjoy a period of hegemony. While most critics recognised in the national orientation a way of affirming the place of Croatian music in the European context, Dobronić saw in it a means for the dominance of Croatian music over other musics, which would no longer have anything to say. He saw impressionism as a decadent, but 'genuine expression of the [Roman] Race, which senses that its artistic-creative role ended long ago but still refuses to leave'. ${ }^{22}$ Speaking about contemporary music of German provenance, Dobronić was even more drastic in his judgement: 'heroic pose and moral corruption created the greatest of all eclectics, Rikard [sic] Strauss, the most perverse of all chromaticists, Max Reger, and the most extreme of all composers, Artur [sic] Schönberg'. ${ }^{23}$ However, that did not mean the end of music. Its future was safe thanks to the Slavic peoples. The period of Slavic music would be characterised by 'goodness and inner energy, which have already started to manifest themselves in music through completely new melody and highly autochthonous rhythmic patterns'. ${ }^{24}$

Most representatives of nationally oriented criticism strongly promoted the idea of a (neo-)national orientation in music as an unquestionable necessity, and

Cf. Sanja Majer-Bobetko, 'Glazbena publicistika Nikole Polića' / 'La pubblicistica musicale di Nikola Polić, in: Zbornik radova s Drugog medunarodnog muzikološkog skupa „Antonio Smareglia i njegovo doba”, Novigrad 24-25. rujna I9g9 / Raccolta degli atti del $2^{o}$ convegno internazionale di musicologia "Antonio Smareglia e la sua epoca", Cittanova 24-25 settembre 1999, ed. Ivana Paula Gortan-Carlin, Novigrad 2000, pp. 235-242 / pp. 243-25I.

20 Josip Andreis, Povijest glazbe [History of music], Zagreb 1942, 'Predgovor' [Preface], not paginated.

2I Ibid., p. 6I8.

22 Antun Dobronić, 'Stvaralački duh u muzici' [The creative spirit in music], in: Muzički eseji [Musical essays], Zagreb I922, p. 8.

23 Ibid., p. 9 .

24 Ibid. 
they had a strong impact on composers. One very clear example is that of Krsto Odak. Born in I888, Odak studied composition with Pater Hartmann in Munich and subsequently with Vítězslav Novák in Prague, where he won the grand prix for his Op. I in 1922 (Sonata for violin and piano). That same year, his outstanding chorus Radosna noć u gradu [A joyful night in the town], composed to expressionist verse by Antun Branko Šimić (1898-1925), was performed for the first time, also in Prague. This a cappella chorus for male voices is characterised by very innovative harmonies, showing Odak's tendency toward the new music of the twentieth century. But when he came to Zagreb in 1922 (where he stayed until his death, in 1965), Odak faced the music critics, who emphasised his outstanding professional abilities, but were almost unanimous in pointing out his lack of interest in the national idiom, which was seen as a serious failure. For example, one of the most prominent music critics, and a very popular composer of the time, Lujo Šafranek-Kavić (1882-1940), wrote that Odak was a talented and technically skilled composer but emphasised the following: 'For the artistic value of his works it is irrelevant, but for the nation in general it would be better if he turned toward national music, which could be considerably enriched by his strong talent'. ${ }^{25}$ Another composer and critic, Kazimir Krenedić (I896-1956), did not hesitate to argue: 'It is only bad that $\mathrm{Mr}$ Odak negates folklore'. ${ }^{26}$ Zlatko Grgošević (1900-78), who was also a well-known composer and critic, concluded: 'Mr Odak possesses composition technique that is learned German (not our own), but for all his technique he creates works which lag behind the music of the West'. ${ }^{27}$ So what did Odak do? His response was, it seems to me, an almost apologetic glorification of folklore in his opera Dorica pleše [Dorica dances], of 1934, composed exclusively from folk tunes and texts from the Croatian region of Medimurje. As was later pointed out in music historiography, this concept limited Odak's creative freedom and set him a problem 'that is almost impossible to solve: that of combining scenes of dramatic tension and intensity with folk tunes which lack dramatic quality altogether, or at best possess it to an extent which is totally inadequate'.$^{28}$

Another example should be mentioned here. Even earlier, in 1916, the pianist, composer and music writer Dragan Plamenac (I895-1983) set to music verse by Charles Baudelaire, provoking a strong reaction from critics, for whom his music was simply not national (based on a folk idiom) on one hand and (like Odak's) too modern on the other. That extremely negative criticism might have prompted

25 Lujo Šafranek-Kavić, 'Iz glazbenog svijeta. Krsto Odak. Kompozicijono veče 5. III' [From the musical world. Krsto Odak. A composer's soirée, 5 March], Obzor 67 (1926) no. 65, p. 4.

26 Kazimir Krenedić, 'Odak-Štolcer (XIX. intimno veče)' [Odak-Štolcer (the 19th intimate evening)], Riječ 5 [6!] (1924) no. 40, p. 4.

27 Zlatko Grgošević, 'Kompozicijsko veče Krsta Odaka' [An evening with the music of Krsto Odak], Slobodna tribuna 6 (1926) no. 65I, p. 7.

28 Josip Andreis, Music in Croatia, Zagreb 1974, p. 269. 
Plamenac to turn to scholarship, where he is regarded as the founder of modern Croatian musicology. ${ }^{29}$ In 1939, he emigrated to the US.

In the late I920s and I930s, Marxist criticism emerged. The first in Croatia to speak of music from a Marxist standpoint was the musicologist and composer Pavao Markovac (1903-4I), who studied musicology with Guido Adler and composition with Hans Gál (192I-26) in Vienna, gaining a PhD in musicology. Markovac’s approach to the study of music and music history is an integral one, in accordance with his Marxist views: sociological, aesthetic, historical and psychological, with the emphasis on the first of these four aspects. He considered music to be a means of ideological struggle and dealt with art in terms of 'a mirror of reality'. At the same time, he believed that art helped to forge a new kind of reality. In addition, he claimed that music, like all other cultural activity, could be related to social classes, and he showed particular interest in the middle class and its rise and fall in relation to music. As a means of ideological struggle, music was utilitarian in nature. In other words, utilitarianism was an essential criterion of the evaluation of an artistic work. Nevertheless, Markovac did realise the necessity of other, 'pure' artistic criteria, on the basis of which a work of art could be assigned objective artistic value for all epochs, although he himself did not provide any such criteria. He was aware of the specific character of art, and whilst insisting on the close relationship between music and society he did not neglect the internal principles of music. For him, the only way to develop a sense of real artistic values was to learn those principles. Markovac assigned special roles in this development to musicology, tasked with facilitating dialectic insight into all the developmental processes in the history of music, and to music criticism based on a thorough knowledge of music. So he avoided the vulgar model of the 'proletkult', which negated the cultural heritage of the past. Although it seems at times that Markovac tends towards sociologism and vulgar economism, a more careful study of his writings reveals that he was aware of the special character of the artistic world. Insisting on the social conditioning of artistic developments, he did not neglect their inner laws. Finally, he was also interested in nationalism in music. For him, nationalism in the music of the nineteenth and early twentieth centuries, which he named 'Romantic nationalism', meant nothing more than the repeated exposure of middle-class ideology, which saw country life and folk music as merely decorative elements without any contact with real life. But nationalism was also acceptable and even desirable when it followed Markovac's basic demand that art be

29 Plamenac studied composition with Schreker in Vienna (I9I2) and Vítězslav Novák in Prague (I9I9), and musicology with Pirro at the Sorbonne and with Adler in Vienna, where he gained his PhD in 1925. On Plamenac see Koraljka Kos, 'In memoriam. Dragan Plamenac', Arti musices I4 (1983) no. I, pp. 3-4; eadem, 'Dragan Plamenac - istraživač i objavljivač rane glazbe' [Dragan Plamenac: Researcher and editor of early music], Arti musices 17 (1986) no. 2, pp. 159-173; Dragan Plamenac, Glazba 16. i 17 . stoljeća u Dalmaciji. Osam studija [Music of the sixteenth and seventeenth centuries in Dalmatia. Eight studies], ed. Ennio Stipčević, Split-Zagreb 1998. 
realistic, which meant that rustic life should not be idealised. In that context, neither Odak's Dorica pleše nor Gotovac's masterpiece Ero s onoga svijeta [Ero the joker], from 1935, which was based on a folk tale and the South Slavic folk music idiom and, as 'a true folk opera [...] pulsates with the life of a genuine theatrical work', ${ }^{30}$ satisfied Markovac's criterion of realism. According to Markovac, they 'solved only the artistic but not the conceptual side'31 of the operas, which were simply not realistic. 'In short, we would finally like to feel the sharp, but convincing, shocking breath of reality on the stage'. ${ }^{32}$ Mussorgsky was the first and the only representative of such 'realistic nationalism' in music, just as Markovac was the first and the only Croatian music critic of the inter-war period to speak about music exclusively from Marxist standpoints. But unlike his Croatian contemporaries, who promoted national ideology, he had no significant impact on music at that time. ${ }^{33}$

At the end of the period in question, the composer Milo Cipra (1906-85) focused his interest on immanent artistic values, shunning any ideological utilitarianism, insisting on the highest artistic criteria and anticipating phenomenological criticism in music. He based his criticism on the philosophical and aesthetic background of German classical philosophy and on romantic interpretations of music. Cipra was a critic with a strong personality, rich intellectual potential and outstanding literary qualities. His articles reveal an author with a refined critical style, based on the positive stylistic achievements of impressionist criticism, making him a unique exception in the field of Croatian music criticism between the two world wars. ${ }^{34}$

We should consider the profile of the music critics of those times. Unlike the very common European practice of the nineteenth century, Croatian composers, as far as we know, avoided music criticism, which was written mainly by writers, poets, music teachers, etc. As a substantial part of the criticism was anonymous, however, some of it could have been written by composers. The musical education of nineteenth-century Croatian music critics is in most cases completely unknown. As already pointed out, only Franjo Kuhač and Vjenceslav Novak had professional higher musical education. That could explain why Croatian music criticism in German - as Snježana Miklaušić-Ćeran and Lovro Županović concluded - was in general more professional and written with greater skill than criticism written in Croatian during

30 J. Andreis, Music in Croatia, op. cit., p. 295.

3I Pavao Markovac, 'Jakov Gotovac: “Ero s onoga svijeta”. Komična opera u tri čina, riječi Milana Begovića' [Jakov Gotovac: Ero the Joker. A comic opera in three acts, with words by Milan Begović], Književnik 9 (I936) no. I, pp. 46-47.

32 Ibid., p. 46.

33 On Markovac see Andrija Tomašek, Pavao Markovac. Čovjek i djelo [Pavao Markovac. The man and his work], Zagreb i983; Sanja Majer-Bobetko, Glazbena kritika na hrvatskom jeziku izmedu dvaju svjetskih ratova [Music criticism in Croatian between the two world wars], Zagreb I994, pp. 48-63. 
the nineteenth century, especially the first half of that century. ${ }^{35}$ From the I870s onwards, that situation gradually changed, first with Franjo Kuhač and Vjenceslav Novak in a professional sense, and finally with Antun Gustav Matoš, who brought impressionist music criticism into the Croatian musical and culturological space. As we have seen, the professionalisation of Croatian music criticism intensified during the twentieth century, and the art of music criticism, besides writers, poets, etc., began to attract both composers and musicologists.

In conclusion, it may be said that no matter who the critics of the period under consideration were, they tried - sometimes successfully - to meet professional artistic criteria, but were not immune to ideologies. From the beginning of the nineteenth century to World War II, Croatian music criticism, at least that written in Croatian, was to a large extent closely connected with national ideology, promoting the idea of music as a means of national affirmation. Like the less influential, but also ideologically oriented, Marxist criticism, it often involved a marked tendency towards criticism 'from above'; that is, normative criticism, which, in addition to discussing music, seeks to prescribe artistic principles.

\section{MIĘDZY MUZYKĄ A IDEOLOGIĄ: CHORWACKA KRYTYKA MUZYCZNA OD JEJ POCZĄTKÓW DO II WOJNY ŚWIATOWEJ}

Ziemie chorwackie były obiektem agresywnej polityki austriackiej, węgierskiej i włoskiej do I wojny światowej, a w niektórych regionach nawet dłużej, stąd też językiem lokalnej krytyki muzycznej był zarówno chorwacki, jak i niemiecki i włoski. Zgodnie z obecnym stanem wiedzy, historia chorwackiej krytyki muzycznej rozpoczęła się w I826 r., kiedy w piśmie literacko-rozrywkowym Luna anonimowy autor opublikował tekst w języku niemieckim.

Forum krytyki muzycznej w języku chorwackim stała się w I835 r. Danica horvatska, slavonska i dalmatinska - dodatek literacki do pisma Novine Horvatzke, które oficjalnie rozpoczęło propagowanie chorwackiego odrodzenia narodowego, uruchamiając proces tworzenia narodu chorwackiego we współczesnym sensie tego słowa. Publikowanych na łamach Danicy artykułów nie można jednak uznać za krytykę muzyczną, przynajmniej nie w obecnym rozumieniu, ponieważ nigdy nie przekraczały one granic zwykłych sprawozdań prasowych.

Za pierwszy poważny tekst krytycznomuzyczny w języku chorwackim powszechnie uważa się obszerną recenzję poety Stanka Vraza (I8IO-5I) z wystawienia pierwszej chorwackiej opery narodowej Vatroslava Lisinskiego (I819-54) pt. Ljubav i zloba (Miłość i złośliwość) z I846 roku. Wypowiedź ta, w której podkreślono dwa aspekty dzieła - narodowy i artystyczny - stała się, jeśli chodzi o przyjęte kryteria oceny, wzorem dla większości dziewiętnastowiecznej i późniejszej chorwackiej krytyki muzycznej. Te wyżej wymienione dwa p. II8. 
podstawowe kryteria możemy zaobserwować bez względu na to, czy mamy do czynienia z: I) krytyką ideologiczno-użytkową, która była zorientowana na promowanie ideologii narodowej (Franjo Ksaver Kuhač, (I834-I9II), Antun Dobronić (I878-I955)), 2) krytyką impresjonistyczną, opartą na subiektywnym podejściu krytyka do poszczególnych dzieł (Antun Gustav Matoš (I873-I9I4), Milutin Cihlar Nehajev (I880-I93I), Nikola Polić (I890-I960), czy 3) krytyką marksistowską (Pavao Markovac (I903-4I)). Dopiero pod koniec rozważanego okresu kompozytor Milo Cipra (1906-85) skupił się na immanentnych wartościach artystycznych, odrzucając wszelkie ideologiczne utylitaryzmy i kładąc nacisk na najwyższe kryteria artystyczne.

Przekt. Jolanta Guzy-Pasiak

Keyworda/słowa kluczowe: Danica horvatska, slavonska i dalmatinska, history of music in Croatia / historia muzyki w Chorwacji, Ljubav i zloba, Stanko Vraz, Franjo Ksaver Kuhač.

Sanja Majer-Bobetko has been working at the Department for the History of Croatian Music of the Croatian Academy of Sciences and Arts since 1993. She was president of the Croatian commission of RILM, and editor-in-chief of the periodical Arti musices (2006-15), as well as head of the research project Croatian music historiography until 1945 . She has published over 200 papers and books, including Estetika glazbe u Hrvatskoj u Ig. stoljeću (The aesthetics of music in croatia in the 19th century, 1979), Osnove glazbene kulture (Basics of Music Culture, 1991) and Glazbena kritika na hrvatskom jeziku izmedu dvaju svjetskih ratova (Music criticism in the croatian language between the two wWorld Wars, 1994). smb@hazu.hr

\title{
Recently published books by Liber Pro Arte
}

\author{
Ars musica and Its Contexts in Medieval and Early Modern Culture \\ edited by Pawet Gancarczyle
}

Music Migration in the Early Modern Age: Centres and Peripheries

- People, Works, Styles, Paths of Dissemination and Influence edited by Jolanta Gusy-Pasiak do Aneta Markuszewska

$$
\text { iswydawnictwo@ispan.pl }
$$

